\title{
Coleoptera assemblages from the Quaternary deposits of Kizikha river, the southernmost late Pleistocene insects of the West Siberian Plain
}

\author{
A.A. Gurina ${ }^{1}$, R.Yu. Dudko ${ }^{1}$, A.S. Prosvirov ${ }^{2}$, S.E. Tshernyshev ${ }^{1,3}$, \\ A.A. Legalov ${ }^{1,3^{*}}$, E.V. Zinovyev ${ }^{4}$ \\ ${ }^{I}$ Laboratory of Phylogeny and Faunogenesis, Institute of Systematics and Ecology of Animals, \\ Siberian Branch of Russian Academy of Sciences, Frunze Street 11, Novosibirsk 630091, Russia. \\ ${ }^{2}$ Faculty of Biology, Moscow State University, Leninskie Gory 1/12, Moscow 119234, Russia. \\ ${ }^{3}$ Tomsk State University, Lenina Prospekt 36, Tomsk 634050, Russia. \\ ${ }^{4}$ Laboratory of Phylogenetics and Biochronology, Institute of Plant and Animal Ecology, Ural \\ Branch of Russian Academy of Sciences, Vos'mogo Marta Street 202, Yekaterinburg 620144, \\ Russia. \\ *Corresponding author: fossilweevils@gmail.com
}

ABSTRACT: Two sites with insect remains were found in an exposure on the bank of Kizikha river, in the Rubtsovskii District of the Altaiskii Krai of Russia, Kizikha-1 with radiocarbon age $13455 \pm 150{ }^{14} \mathrm{C} \mathrm{BP}(\mathrm{SPb}-1347)$, and Kizikha-2 with the age $26094 \pm 400$ ${ }^{14} \mathrm{C}$ BP $(\mathrm{SPb}-1418)$. This period is coincides with Sartan stadial and Kargin interstadial (MIS 2 and MIS 3). This is the southernmost late Pleistocene insect bearing deposit found in West Siberia. The fragments in both sites are represented mainly by Coleoptera. Beetle fauna from the site Kizikha- 1 is represented by 34 species from 9 families. The majority of fragments belong to weevils and ground beetles. 28 species from 8 families are found in Kizikha-2 site, the majority of fragments belong to Carabidae. 7 species found in the sites, Dyschiriodes rufimanus, Cymindis cf. rostowtzowi (Carabidae), Cidnopus cf. parallelus, Pristilophus punctatissimus (Elateridae), Hemitrichapion alexsandri (Brentidae), Paophilus albilaterus and Otiorhynchus sushkini (Curculionidae), are recorded in Pleistocene deposits for the first time. Sub-fossil insect assemblages of the two sites coincides with the late Pleistocene "Otiorhynchus-type" sub-fossil insect fauna from southeastern part of West-Siberian Plain (Zinovyev, 2011; Legalov et al., 2016) with characteristics as follows: dominance of steppe species, presence of halophile species, lack of forest species. Most of these species are absent in the contemporary regional fauna. The complex of eastern species and presence of endemics of Altai-Sayan Mountain system is also characteristic to the both studied sites. Specifics of the deposit assemblages in comparison with the other late Pleistocene fauna of West Siberian Plain is in high share of meadow species that could be explained by taphonomic condition of sedimentation or microclimatic conditions caused by close location to Altai mountains. Analysis of sub-fossil insect fragments showed that open landscapes with zonal steppe and sparse meadow vegetation near rivers and in depressions were typical for this area. In comparison to contemporary conditions climate was dry and cold, but Kizikha-2 (end of MIS 3) was formed in more mild climate conditions than Kizikha-1 (end of MIS 2). Results gained from Kizikha-1 and Kizikha-2 sites are complementing data on latitudinal-zonal distribution of beetles found in late Pleistocene deposits in West Siberian Plain.

How to cite this article: Gurina A.A., Dudko R.Yu., Prosvirov A.S., Tshernyshev S.E., Legalov A.A., Zinovyev E.V. 2019. Coleoptera assemblages from the Quaternary deposits of Kizikha river, the southernmost late Pleistocene insects of the West Siberian Plain // Invert. Zool. Vol.16. No.2. P.165-182. doi: 10.15298/invertzool.16.2.05 
KEY WORDS: paleoentomology; sub-fossil insects; late Pleistocene; Kargin interglacial; Sartan stadial; Siberia; Otiorhynchus-type fauna.

\title{
Комплексы жесткокрылых из четвертичных отложений р. Кизиха - самые южные позднеплейстоценовые насекомые Западно- Сибирской равнины
}

\author{
А.А. Гурина', Р.Ю. Дудко1, А.С. Просвиров ${ }^{2}$, С.Э. Чернышёв ${ }^{1,3}$, \\ А.А. Легалов ${ }^{1,3^{*}}$, Е.В. Зиновьев ${ }^{3}$ \\ ${ }^{1}$ Институт систематики и экологии животных СО РАН, ул. Фрунзе 11, Новосибирск \\ 630091, Россия. \\ ${ }^{2}$ Биологический факультет Московского государственного университета, Ленинские горы \\ 1, стр. 12, Москва 119234, Россия. \\ ${ }^{3}$ Томский государственный университет, проспект Ленина 36, Томск 634050, Россия. \\ ${ }^{4}$ Лаборатория филогенетики и биохронологии, Институт экологии растений и животных \\ УрО РАН, ул. 8 Марта 202, Екатеринбург 620144, Россия. \\ *Автор для переписки: fossilweevils@gmail.com
}

РЕЗЮМЕ: На реке Кизиха Алтайского края найдены два захоронения макроостатков насекомых, Кизиха-1 с радиоуглеродным возрастом 13455 150 лет назад (SPb-1347) и Кизиха- 2 - 26094 400 лет назад (SPb-1418), что соответствует концу сартанского стадиала и концу каргинского межстадиала (МИС-2 и МИС-3). Это самые южные в Западной Сибири местонахождения позднеплейстоценовых насекомых. Остатки насекомых обоих местонахождений представлены преимущественно жесткокрылыми. В местонахождении Кизиха-1 найдено 34 вида Coleoptera из 9 семейств, преобладают виды Curculionidae и Carabidae. В местонахождении Кизиха-2 найдено 28 видов Coleoptera из 8 семейств, причём и по числу видов и числу фрагментов преобладают Carabidae. 7 видов из этих местонахождений, Dyschiriodes rufimanus, Cymindis cf. rostowtzowi (Carabidae), Cidnopus cf. parallelus, Pristilophus punctatissimus (Elateridae), Hemitrichapion alexsandri (Brentidae), Paophilus albilaterus и Otiorhynchus sushkini (Curculionidae), в плейстоценовых отложениях найдены впервые. Комплексы жесткокрылых обоих местонахождений в целом соответствуют позднеплейстоценовой «отиоринхусной» фауне южной части Западно-Сибирской равнины (Zinovyev, 2011; Legalov et al., 2016). Характерные черты этих фаун: преобладание степных видов, присутствие галобионтов, отсутствие лесные видов. Кроме того, большая часть видов сейчас отсутствует в региональных фаунах. Характерно наличие восточного комплекса видов, в том числе эндемиков межгорных котловин Алтае-Саянской горной системы. Специфическая особенность обоих местонахождений, по сравнению с другими позднеплейстоценовыми фаунами Западно-Сибирской равнины, является высокая доля луговых видов, что может быть связано либо с тафономическими условиями захоронений, либо с микроклиматическими условиями, обусловленными близостью алтайских гор. Для обоих местонахождений реконструируются открытые степные и луговые ландшафты. Вероятно, основным зональным ландшафтом была степь, а луга занимали поймы рек и другие понижения рельефа. Климат, по сравнению с современным, был сухим и холодным. При этом условия времени 
образования захоронения Кизиха-2 (конец МИС-3) были несколько более мягкими, по сравнению с условиями захоронения Кизиха-1 (конец МИС-2). Полученные данные из местонахождений Кизиха-1 и Кизиха-2 дополнили известные ранее сведения по широтно-зональному распределению позднеплейстоценовых жесткокрылых Западно-Сибирской равнины.

Как цитировать эту статью: Gurina A.A., Dudko R.Yu., Prosvirov A.S., Tshernyshev S.E., Legalov A.A., Zinovyev E.V. 2019. Coleoptera assemblages from the Quaternary deposits of Kizikha river, the southernmost late Pleistocene insects of the West Siberian Plain // Invert. Zool. Vol.16. No.2. P.165-182. doi: 10.15298/invertzool.16.2.05

КЛЮЧЕВЫЕ СЛОВА: палеоэнтомология, поздний плейстоцен, субфоссильные насекомые, каргинский межстадиал, сартанский стадиал, отиоринхусная фауна.

\section{Introduction}

Insect remains as well as other sub-fossil groups are widely used for reconstructing natural conditions of the Pleistocene and Holocene that traditionally have been studied in Russia in the north-eastern territories of Siberia (Sher et al., 2005; Sher, Kuzmina, 2007; Kuzmina, 2015). Study of insects in Quaternary deposits of West Siberian Plain began in 1970s (Kiselev, 1973, 1988 ) and now significant material is accumulated from northern and central parts of West Siberian Plain and the Urals $\left(\mathrm{N} 70^{\circ}-57^{\circ}\right)$. More than 130 sites with insect remains of different ages from Pleistocene to Holocene are known from this territory (Zinovyev, 2008, 2011; Sheinkman et al., 2016; Rusakov et al., 2019). In a course of the expedition trips 2012-2014 in southern part of West Siberian Plain insect remains were found on banks of rivers $\mathrm{Ob}$, Chik, Suzun, Chumysh, Alei, Ustianka and Kizikha (Tsepelev et al., 2013; Tshernyshev et al., 2013; Gurina et al., 2016, 2018, 2019; Legalov, Dudko, 2016; Zinovyev et al., 2016). These studies increase our knowledge about late Pleistocene entomofauna of West Siberian Plain and indicating patterns of changes in insect assemblages along latitudinal - zonal gradient. Two southernmost late Pleistocene sites were found in an exposure on the bank of Kizikha river, in the Rubtsovskii District of the Altaiskii Krai region of Russia, and were named as Kizikha-1 with radiocarbon age $13455 \pm 150{ }^{14} \mathrm{CBP}(\mathrm{SPb}-1347)$, and Kizikha-2 with the age $26094 \pm 400{ }^{14} \mathrm{C}$ BP ( $\mathrm{SPb}-1418)$. This period is coincides with Sar- tan stadial and Karginian interstadial (MIS 2 and MIS 3). Description of insect assemblages from these sites is given below.

At present the region of study is under feather-grass steppe landscapes located nearly the Altai mountains foothills. Dry and warm climate is typical of the southern parts of the Altaiskii Krai with January being the coldest month with $-17.8^{\circ} \mathrm{C}$ average temperature and July the warmest with $+20.3{ }^{\circ} \mathrm{C}$ average temperature (Revyakin, 1995).

Kizikha river is right tributary of Alei river and extents about $50 \mathrm{~km}$ on Pre-Altai Plain in sub-meridional direction. Valley at the river source is interposed with granitic bedrocks and at the remaining part to Upper Miocene-Lower Quaternary deposits (Rusanov, 2010).

Sub-fossil material was described from the middle reaches of the river from the profile with the lower part at 1.7-5.9 $\mathrm{m}$ depth, containing green-grey clay included alluvial detritus have yielded both spore-pollen and seed floras, mollusks, ostracods, and numerous bones of small mammals (Adamenko, 1974). On the basis of the identification presented the deposits were attributed to second half of Upper Pliocene. Green-grey clay layer is stated as stratotype of Kizikha Member forming middle part of Kochkovskaya Formation (Adamenko, 1974). In later works the Kochkovskaya Formation was attributed to Eopleistocene age (Zazhigin, 1980; Unified ..., 2000). Lower the deposit (5.9-6.8 $\mathrm{m}$ ) is a layer of red-brown clays with large gypsum crystals which is considered as belonging to Pavlodarskaya Formation of Upper Mi- 
Table 1. Description of the Kizikha-1 section. Таблица 1. Описание отложений разреза Кизиха-1.

\begin{tabular}{|c|c|c|c|}
\hline $\begin{array}{l}\text { Layer } \\
\text { No. }\end{array}$ & $\begin{array}{l}\text { Depth of } \\
\text { bedding, } \mathrm{m}\end{array}$ & $\begin{array}{c}\text { Thickness, } \\
\text { m }\end{array}$ & Description \\
\hline 1 & $0.0-0.8$ & 0.8 & Modern soil \\
\hline 2 & $0.8-1.7$ & 0.9 & Dark-grey sandy loam, dense, dry, porous \\
\hline 3 & $1.7-1.8$ & 0.1 & Interlayer with buried soil \\
\hline 4 & $1.8-2.7$ & 0.9 & $\begin{array}{l}\text { Light-grey loam, dense, with ferruginous } \\
\text { interlayer and lenses of coarse-grained sand }\end{array}$ \\
\hline 5 & $2.7-2.73$ & 0.03 & Lens of coarse-grained sand \\
\hline 6 & $2.73-5.85$ & 3.12 & $\begin{array}{l}\text { A yellow-brown loam, dense, with ferruginous } \\
\text { interlayers }\end{array}$ \\
\hline $7 *$ & $5.85-6.3$ & $>0.45$ & $\begin{array}{l}\text { Gray-blue clay with inclusions of plant detritus } \\
\text { and insect remains. The layer extends under water } \\
\text { surface }\end{array}$ \\
\hline
\end{tabular}

* Insect remains: Sample 1 (5.85-5.95 m from the surface), sample 2 (6.0-6.15 m from the surface), sample 3 (3 $\mathrm{m}$ to the right, $6.0-6.3 \mathrm{~m}$ from the surface); phytodetritus for dating is taken from sample 1 .

* остатки насекомых: проба 1 (глубина 5,85-5,95 м), проба 2 (глубина 6,0-6,15м), проба 3 (3м правее осной расчистки, глубина 6,0-6,3м); растительный детрит на определение возраста ${ }^{14} \mathrm{C}$ из пробы 1 .

ocene. The stratotypical profile of Kizikha Member and the other similar exposition near the river were re-studied (Rusanov, 2010), radiocarbon dating of vegetation remains produced early-middle Holocene age. As a result, Pliocene-Eopleistocene material from the Kizikha profile is considered as redeposited. This fact agrees with Ostracoda faunal data gained before as "typical Holocene assemblage with more old species from Pliocene and Low Quaternary deposits" (Kazmina, 1975).

The Kizikha-1 and Kizikha-2 sites are located $20 \mathrm{~km}$ upstream the stratotypical profile. Recently found late Pleistocene layers with insect remains are not equivalent to data profiles from central part of the river course of the river and cannot be compared with the other paleomaterial from Kizikha river.

\section{Materials and methods}

The deposit Kizikha-1 is located on the right bank of the Kizikha river in a $6.3 \mathrm{~m}$ cliff, in the upper reaches of Kizikha river, in the Rubtsovskii District of the Altaiskii Krai region of Russia. The site coordinates are: $51^{\circ} 26^{\prime} 21.9^{\prime \prime}$ $\mathrm{N}, 81^{\circ} 36^{\prime} 18.9^{\prime \prime} \mathrm{E}$. A sedimentary description of the Kizikha-1 deposit profile is presented in Table 1 by E.V. Zinovyev. The lowest layer 7 of the section (grey-blue clay) contains alluvial detritus with insect remains. Three samples for entomological and radiocarbon analysis were taken from this deposit in July 29, 2013 by A.A. Gurina, R.Yu. Dudko and E.R. Dudko.

The deposit Kizikha-2 is located on the left bank of the Kizikha river in a $10.6 \mathrm{~m}$ cliff, in the $1.2 \mathrm{~km}$ lower of the Kizikha-1 deposit, in the Rubtsovskii District of the Altaiskii Krai region of Russia. The site coordinates are: $51^{\circ} 27^{\prime} 00.0^{\prime \prime}$ $\mathrm{N}, 81^{\circ} 36^{\prime} 22.2^{\prime \prime}$ E. A sedimentary description of the Kizikha-2 deposit profile is presented in Table 2 by E.V. Zinovyev. The lowest layer 7 of the section (alternating coarse-grained sand and gray loam) contains alluvial detritus with insect remains. A sample for entomological and radiocarbon analysis was taken from this deposit in July 29, 2013 by E.V. Zinovyev, K.A. Tsepelev and A.A. Legalov.

Sampling methods follow those of Coope (1959) with later updates (Gurina et al., 2016).

Radiocarbon dating of the samples was undertaken by M.A. Kul'kova in Herzen State Pedagogical University, Saint-Petersburg. Wooden and herbal remains from the same 
Table 2. Description of the Kizikha-2 section. Таблица 2. Описание отложений разреза Кизиха-2.

\begin{tabular}{|c|c|c|c|}
\hline $\begin{array}{l}\text { Layer } \\
\text { No. }\end{array}$ & $\begin{array}{c}\text { Depth of } \\
\text { bedding, } \\
\text { m }\end{array}$ & $\begin{array}{c}\text { Thickness, } \\
\text { m }\end{array}$ & Description \\
\hline 1 & $0.0-0.8$ & 0.8 & Modern soil, humus \\
\hline 2 & $0.8-3.3$ & 2.5 & $\begin{array}{l}\text { Light-yellow sandy loam, dense, columnar, with } \\
\text { ferruginous interlayers }\end{array}$ \\
\hline 3 & $3.3-5.1$ & 1.8 & $\begin{array}{l}\text { Light-brown sandy loam, dense, with ferruginous } \\
\text { interlayers }\end{array}$ \\
\hline 4 & $5.1-7.0$ & 1.9 & $\begin{array}{l}\text { Brownish-yellow loam with ferruginous } \\
\text { interlayers and a weak interlayer of gravel and } \\
\text { interlayer of coarse sand } 3 \mathrm{~cm} \text { thickness in upper } \\
\text { side } 5.5 \mathrm{~cm} \text { from the margin }\end{array}$ \\
\hline 5 & $7.0-7.45$ & 0.45 & Yellow-brownish coarse sand with gravel \\
\hline 6 & $7.45-9.95$ & 2.5 & $\begin{array}{l}\text { Bluish-grey loam, dense, with ferruginous } \\
\text { interlayers and inclusions of plant detritus }\end{array}$ \\
\hline $7 *$ & $9.95-10.6$ & $>0.65$ & $\begin{array}{l}\text { Alternating coarse-grained sand and with brown } \\
\text { gravel and gray loam wich includes arboreal } \\
\text { remains, alluvial detritus and insect remains }\end{array}$ \\
\hline
\end{tabular}

\footnotetext{
* Sample 9.95-10.6 m from the surface with insect remains and phytodetritus for dating.

* проба с глубины 9,95-10,6 м содержала остатки насекомых и растительный детрит, по которому получена ${ }^{14} \mathrm{C}$ датировка.
}

layers as that containing insect fragments were taken for the analysis. The sample 1 from Kizikha-1 age is $13455 \pm 150{ }^{14} \mathrm{C} \mathrm{BP}(\mathrm{SPb}-1347)$, and the sample from Kizikha-2 age is 26094 \pm $400{ }^{14} \mathrm{C}$ BP (SPb-1418).

The index of minimal number of specimens, $N_{\text {min }}$, reckoned for each species as maximal number of one type fragments (heads, pronotum, left or right elytra) was used for evaluation of specimen quantity in samples.

\section{Results}

335 insect fragments from three orders, Coleoptera, Hymenoptera and Diptera, of which 332 fragment belong to Coleoptera are gained from Kizikha-1 site. Coleopteran fauna from the site is represented at least by 34 species from 9 families (Table 3). The majority of fragments (14 and 7 species, 62\%) belong to weevils and ground beetles. Cymindis cf. rostowtzowi (Carabidae), Cidnopus cf. parallelus, Pristilophus punctatissimus (Elateridae), Hemitrichapion alexsandri (Brentidae), Paophilus albilaterus and Otiorhynchus sushkini (Curculionidae) are recorded in Pleistocene assemblages for the first time (Figs 1-2). The most abundant in number of species are Otiorhynchus, 7 species, and Sitona, 3 species (Fig. 2F-I). The majority of specimens $\left(N_{\min }=99 \mathrm{spm}\right.$. (71\%) from the deposit belong to Curculionidae, less numerous $\left(N_{\min }=13\right.$ spm. $\left.(9 \%)\right)$ are Carabidae. Otiorhynchus species are the most numerous (50\%), dominated by Otiorhynchus politus $\left(N_{\min }=35\right)$, O. ursus $\left(N_{\min }=10\right)$, O. altaicus, O. obscurus and $O$. unctuosus $\left(N_{\min }=7\right)$. Also abundant is species Sitona ovipennis $\left(N_{\min }=17 \mathrm{spm} .(12 \%)\right)$.

The lists of species from three samples taken from Kizikha-1 site are moderately similar. Pairwise similarity indexes for the presence / absence of species are $64-85 \%$. By the quantitative indexes differs the $3^{\text {rd }}$ sample (similarity $45 \%$ ) (Table 4). In this sample dominate Otiorhynchus ursus (25\%), and also abundant are specimens of $O$. altaicus (14\%) and O. politus (14\%).

339 insect fragments from two orders, Coleoptera and Hymenoptera, are found in Kiz- 
Table 3. Species composition and number of insect fragments in Kizikha-1 and Kizikha-2 sub-fossil insect assemblage.

Таблица 3. Видовой состав и число фрагментов насекомых в тафоценозах Кизиха-1 и Кизиха-2.

\begin{tabular}{|c|c|c|c|c|c|}
\hline \multirow{2}{*}{ No. } & \multirow{2}{*}{ Species } & \multicolumn{3}{|c|}{ Kizikha-1 } & \multirow{2}{*}{ Kizikha-2 } \\
\hline & & Sample 1 & Sample 2 & Sample 3 & \\
\hline \multicolumn{6}{|c|}{ Coleoptera } \\
\hline \multicolumn{6}{|c|}{ Carabidae } \\
\hline 1 & Clivina fossor (Linnaeus, 1758) & $1 / 0-1-0-0^{*}$ & $2 / 2-1-0-0$ & - & - \\
\hline 2 & $\begin{array}{l}\text { Dyschiriodes rufimanus (A. } \\
\text { Fleischer, 1898) }\end{array}$ & - & - & - & $1 / 0-0-2-0$ \\
\hline- & Dyschiriodes sp. & - & - & - & $2 / 1-2-1-0$ \\
\hline 3 & $\begin{array}{l}\text { Bembidion (Chlorodium) almum } \\
\text { J.R. Sahlberg, } 1900\end{array}$ & - & - & - & $2 / 0-0-3-0$ \\
\hline 4 & Bembidion (Emphanes) sp. & - & - & - & $1 / 0-1-0-0$ \\
\hline 5 & $\begin{array}{l}\text { Bembidion (Plataphodes) cf. } \\
\text { fellmanni (Mannerheim, 1823) }\end{array}$ & - & - & - & $1 / 0-0-1-0$ \\
\hline 6 & $\begin{array}{l}\text { Bembidion (Peryphus) obscurellum } \\
\text { (Motschulsky, 1845) }\end{array}$ & - & - & $1 / 0-0-2-0$ & - \\
\hline 7 & Bembidion (Ocydromus s.1.) spp. & - & - & $1 / 0-1-0-0$ & $3 / 0-1-3-0$ \\
\hline- & Bembidion spp. & - & - & $1 / 1-0-1-0$ & $8 / 1-1-16-2$ \\
\hline 8 & Pogonus punctulatus Dejean, 1828 & - & - & - & $2 / 0-0-3-1$ \\
\hline 9 & $\begin{array}{l}\text { Poecilus cf. hanhaicus } \\
\text { (Tschitschérine, 1894) }\end{array}$ & - & $1 / 0-1-0-0$ & $1 / 0-0-1-0$ & - \\
\hline 10 & Poecilus cf. ravus (Lutschnik, 1922) & - & - & - & $2 / 0-2-0-0$ \\
\hline- & Poecilus sp. & $1 / 1-0-1-0$ & - & - & - \\
\hline 11 & Pterostichus sp. & - & - & - & $4 / 0-0-4-0$ \\
\hline 12 & Harpalus sp. & - & - & - & $1 / 1-1-0-0$ \\
\hline 13 & Amara aurichalcea Germar, 1823 & - & - & - & $2 / 0-2-0-0$ \\
\hline 14 & Amara sp.1 & - & - & - & $1 / 0-0-1-0$ \\
\hline 15 & Curtonotus torridus (Panzer, 1796) & - & $1 / 0-1-1-0$ & - & - \\
\hline 16 & Curtonotus sp.1 & - & $1 / 0-1-0-0$ & - & - \\
\hline- & Curtonotus sp. & - & - & - & $1 / 0-0-1-0$ \\
\hline 17 & $\begin{array}{l}\text { Cymindis cf. rostowtzowi } \\
\text { Tschitschérine, } 1896\end{array}$ & - & - & $2 / 0-0-3-0$ & - \\
\hline- & Cymindis sp. & $1 / 1-0-0-0$ & - & - & - \\
\hline- & Carabidae indet. & $1 / 1-0-0-1$ & - & - & $\begin{array}{c}5 / 3-1-11- \\
22 \\
\end{array}$ \\
\hline \multicolumn{6}{|c|}{ Silphidae } \\
\hline 18 & Aclypea opaca (Linnaeus, 1758) & - & - & - & $5 / 0-5-4-1$ \\
\hline- & Aclypea sp. & $3 / 3-1-0-0$ & - & - & $5 / 4-5-1-1$ \\
\hline 19 & $\begin{array}{l}\text { Thanatophilus trituberculatus } \\
\text { Kirby, } 1837\end{array}$ & $1 / 0-0-1-0$ & - & - & - \\
\hline- & Silphidae indet. & - & - & - & $1 / 0-1-2-6$ \\
\hline \multicolumn{6}{|c|}{ Staphylinidae } \\
\hline 20 & Stenus sp. & - & - & - & $1 / 0-0-1-1$ \\
\hline
\end{tabular}


Table 3 (continued). Таблица 3 (продолжение).

\begin{tabular}{|c|c|c|c|c|c|}
\hline 21 & Paederinae indet. & $1 / 1-0-0-0$ & $2 / 1-2-0-0$ & - & - \\
\hline- & Staphylinidae indet. & - & $2 / 1-1-0-0$ & - & $5 / 5-2-2-3$ \\
\hline \multicolumn{6}{|c|}{ Scarabaeidae } \\
\hline 22 & $\begin{array}{l}\text { Aphodius granarius (Linnaeus, } \\
\text { 1767) }\end{array}$ & $3 / 0-0-4-0$ & $2 / 0-1-3-0$ & - & - \\
\hline 23 & Aphodius spp. & $1 / 0-0-0-1$ & - & - & $2 / 0-0-2-1$ \\
\hline \multicolumn{6}{|c|}{ Elateridae } \\
\hline 24 & Hypnoidus sp. riparius-group & $3 / 1-3-2-2$ & $2 / 1-2-3-0$ & - & $1 / 0-1-2-0$ \\
\hline 25 & $\begin{array}{l}\text { Cidnopus cf. parallelus } \\
\text { (Motschulsky, 1860) }\end{array}$ & - & $1 / 0-0-1-0$ & - & - \\
\hline 26 & $\begin{array}{l}\text { Pristilophus punctatissimus } \\
\text { (Ménétriés, 1851) }\end{array}$ & - & $1 / 0-1-1-0$ & - & - \\
\hline 27 & Oedostethus sp. & - & $1 / 0-1-0-1$ & - & - \\
\hline- & Elateridae indet. & - & - & - & $3 / 0-0-5-0$ \\
\hline \multicolumn{6}{|c|}{ Tenebrionidae } \\
\hline 28 & Centorus cf. rufipes (Gebler, 1833) & - & $1 / 0-1-0-0$ & $1 / 0-1-0-0$ & - \\
\hline \multicolumn{6}{|c|}{$\begin{array}{ll}\text { Chrysomelidae } \\
\end{array}$} \\
\hline 29 & Pachnephorus sp. & - & - & - & $1 / 0-0-1-0$ \\
\hline- & Chrysomelidae indet. & $1 / 1-0-0-0$ & - & - & - \\
\hline \multicolumn{6}{|c|}{ Brentidae } \\
\hline 30 & $\begin{array}{l}\text { Hemitrichapion alexsandri Legalov, } \\
2001\end{array}$ & - & $1 / 0-0-2-0$ & - & - \\
\hline 31 & Eutrichapion viciae (Paykull, 1800) & $1 / 1-0-2-0$ & $2 / 0-1-3-0$ & - & - \\
\hline 32 & $\begin{array}{l}\text { Eutrichapion facetum (Gyllenhal, } \\
\text { 1839) }\end{array}$ & - & - & - & $1 / 0-0-2-0$ \\
\hline \multicolumn{6}{|c|}{ Curculionidae } \\
\hline 33 & $\begin{array}{l}\text { Tournotaris bimaculata (Fabricius, } \\
\text { 1787) }\end{array}$ & - & - & - & $1 / 0-0-2-0$ \\
\hline 34 & Stephanocleonus sp. & $2 / 0-2-0-2$ & - & - & - \\
\hline- & Cleoninae indet. & $1 / 0-0-0-3$ & - & - & $1 / 0-0-0-4$ \\
\hline 35 & Zacladus geranii (Paykull, 1800) & - & - & - & $5 / 10-0-0-1$ \\
\hline 36 & $\begin{array}{l}\text { Tychius albolineatus Motschulsky, } \\
1860\end{array}$ & - & $4 / 3-4-4-0$ & $1 / 0-0-1-0$ & - \\
\hline 37 & $\begin{array}{l}\text { Hypera transsylvanica }(\text { Petri, 1901) } \\
\text { / ornata (Capiomont, 1868) }\end{array}$ & - & - & - & $1 / 1-1-0-0$ \\
\hline 38 & Sitona ambiguus Gyllenhal, 1834 & - & $2 / 2-0-0-0$ & - & - \\
\hline 39 & Sitona lineellus (Bonsdorff, 1785) & - & $1 / 0-1-0-0$ & - & - \\
\hline 40 & Sitona ovipennis Hochhut, 1851 & $4 / 4-1-0-0$ & $\begin{array}{c}11 / 11-2-1- \\
0\end{array}$ & $2 / 2-0-1-0$ & - \\
\hline- & Sitona sp. & - & - & - & $1 / 0-1-0-0$ \\
\hline 41 & $\begin{array}{l}\text { Phyllobius femoralis Boheman, } \\
1842\end{array}$ & - & - & - & $3 / 0-0-4-0$ \\
\hline 42 & $\begin{array}{l}\text { Phyllobius virideaeris (Laicharting, } \\
1781 \text { ) }\end{array}$ & - & - & - & $3 / 0-0-4-0$ \\
\hline
\end{tabular}


Table 3 (continued).

Таблица 3 (продолжение).

\begin{tabular}{|c|c|c|c|c|c|}
\hline 43 & $\begin{array}{l}\text { Polydrusus amoenus (Germar, } \\
\text { 1823) }\end{array}$ & - & $1 / 1-0-0-0$ & - & - \\
\hline 44 & Paophilus albilaterus Faust, 1890 & - & $1 / 1-0-0-0$ & - & - \\
\hline 45 & Otiorhynchus altaicus Stierlin, 1861 & $1 / 0-0-2-0$ & $1 / 0-0-2-0$ & $5 / 0-0-8-0$ & $2 / 0-0-3-0$ \\
\hline 46 & Otiorhynchus ursus Arnoldi, 1964 & - & $1 / 0-0-2-0$ & $9 / 0-0-16-0$ & $2 / 0-0-3-0$ \\
\hline- & Otiorhynchus altaicus / ursus & - & $2 / 0-2-0-0$ & $6 / 5-6-0-0$ & $5 / 5-4-0-5$ \\
\hline 47 & $\begin{array}{l}\text { Otiorhynchus obscurus Gyllenhal, } \\
1834\end{array}$ & $2 / 0-0-3-0$ & $2 / 0-2-1-0$ & $3 / 2-3-6-0$ & - \\
\hline 48 & $\begin{array}{l}\text { Otiorhynchus politus Gyllenhal, } \\
1834\end{array}$ & $11 / 9-8-18-0$ & $\begin{array}{c}19 / 19-11- \\
15-0\end{array}$ & $5 / 5-0-0-0$ & - \\
\hline 49 & $\begin{array}{l}\text { Otiorhynchus? subocularis Arnoldi, } \\
1975\end{array}$ & $1 / 1-0-0-0$ & - & - & - \\
\hline 50 & $\begin{array}{l}\text { Otiorhynchus sushkini Arnoldi, } \\
1975\end{array}$ & - & $2 / 2-0-0-0$ & - & - \\
\hline- & Otiorhynchus subocularis / sushkini & - & $3 / 0-0-5-0$ & - & - \\
\hline 51 & $\begin{array}{l}\text { Otiorhynchus unctuosus Germar, } \\
1823\end{array}$ & $3 / 2-3-4-0$ & $1 / 1-1-2-0$ & $3 / 3-3-1-0$ & - \\
\hline- & Otiorhynchus sp. & $2 / 0-0-1-16$ & - & - & $4 / 0-4-8-0$ \\
\hline- & Curculionidae indet. & $1 / 0-0-0-3$ & $1 / 0-0-0-2$ & - & $2 / 0-1-3-6$ \\
\hline- & Coleoptera indet. & $1 / 0-0-1-10$ & $1 / 1-0-2-1$ & $1 / 0-0-2-0$ & $\begin{array}{l}\text { 6/0-3-6- } \\
105\end{array}$ \\
\hline \multirow{2}{*}{\multicolumn{2}{|c|}{ Всего видов Coleoptera }} & 17 & 23 & 12 & \multirow{2}{*}{28} \\
\hline & & \multicolumn{3}{|c|}{31} & \\
\hline & Всего $N_{\min }$ Coleoptera & 40 & 66 & 34 & 74 \\
\hline \multicolumn{6}{|c|}{ Hymenoptera } \\
\hline Hym & noptera indet. & $1 / 0-0-0-1$ & $1 / 0-0-0-1$ & - & $1 / 0-0-0-1$ \\
\hline \multicolumn{6}{|c|}{ Lepidoptera } \\
\hline Lepi & optera indet. & $1 / 0-0-0-1$ & - & - & - \\
\hline \multicolumn{6}{|c|}{ Insecta } \\
\hline Inse & a indet. & $1 / 0-0-0-2$ & $1 / 0-0-0-1$ & - & $? / 0-0-0-7$ \\
\hline
\end{tabular}

$* N_{\min } /$ number of head - pronotum - elytron - other fragments.

$* N_{\text {min }} /$ количество голов - переднеспинок - надкрылий - прочих фрагментов.

ikha-2 site with the only fragment of Hymenoptera. Beetle fauna is represented at least by 28 species from 8 families (Table 3). Only $20 \%$ of the fragments, 15 species, were identified due to poor integrity of the material. The majority of fragments (12 and 9 species, 74\%) belong to ground beetles and weevils. The remaining families were represented by just 1-3 species. The genus Bembidion was represented in the site by 4 species, the remaining genera by
1-2 species. Dyschiriodes rufimanus (Carabidae) is recorded for the first time from Pleistocene deposits. The majority of specimens $\left(N_{\min }=30 \mathrm{spm}\right.$. and $20 \mathrm{spm}$. (68\%) from the deposit belong to Carabidae and Curculionidae, also numerous are Silphidae $\left(N_{\min }=10 \mathrm{spm}\right.$.). The site lacks distinct dominant species, but Aclypea opaca (Silphidae) and Zacladus geranii (Curculionidae) are the most numerous $\left(N_{\min }=5\right.$ spm., $7 \%$ each). 

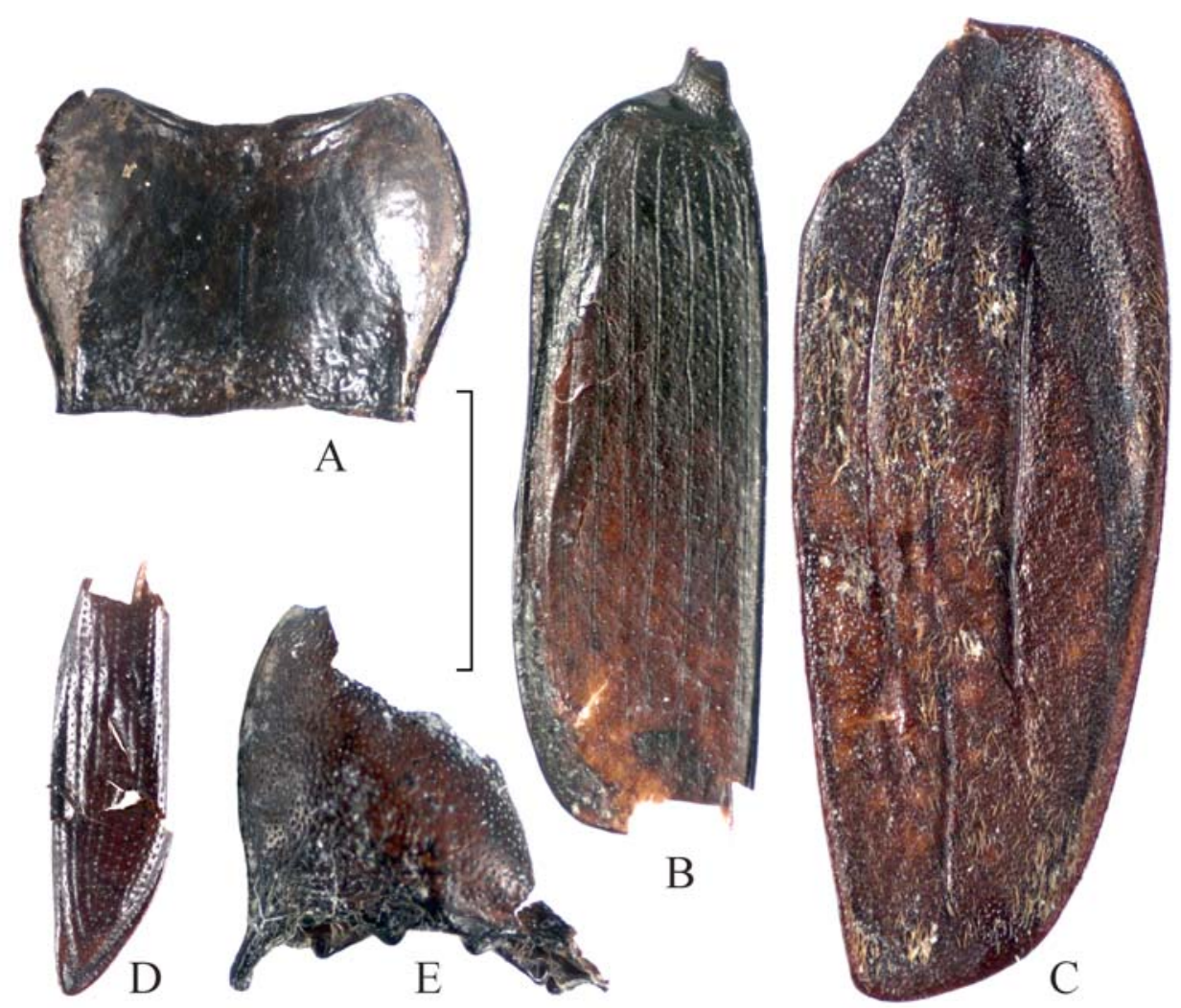

Fig. 1. Sub-fossil beetle fragments from the Kizikha-1 assemblage: A - Curtonotus torridus, B - Cymindis cf. rostowtzowi, C - Thanatophilus trituberculatus, D - Cidnopus cf. parallelus, E - Pristilophus punctatissimus; A, E - pronotum, B-D - elytron. Scale bar $2 \mathrm{~mm}$.

Рис. 1. Фрагменты Coleoptera из местонахождения Кизиха-1: A - Curtonotus torridus, В - Cymindis cf. rostowtzowi, C - Thanatophilus trituberculatus, D - Cidnopus cf. parallelus, E - Pristilophus punctatissimus. A, E - переднеспинка, B-D - надкрылье. Масштабная линейка 2 мм.

\section{Discussion}

\section{Taxonomic composition}

The species composition of sub-fossil insects from the sites Kizikha-1 and Kizikha-2 are extremely different. Only three species occur in sub-fossil assemblages of both sites, two species, Otiorhynchus altaicus $(=$ O. karkaralensis Bajtenov, 1974) and O. ursus (=O. kasachstanicus Arnoldi, 1964), are common residents of sub-fossil assemblages in southern and central parts of West-Siberian Plain (Legalov et al., 2016; Zinovyev et al., 2016; Gurina et al., 2018, 2019).
Comparison of the two sub-fossil insect assemblages with other late Pleistocene sub-fossil insect fauna from southeastern part of WestSiberian Plain (Zinovyev et al., 2016; Gurina et al., 2018, 2019) shows both similarity and specifics of insect composition from the sites Kizikha-1 and Kizikha-2.

It is typical that Curculionidae beetles, especially the Otiorhynchus species are dominant in species richness and specimen numbers in late Pleistocene sub-fossil assemblages. The same taxonomic structure relates to Kizikha-1 site. However, more than a half of species found in the site have not been recorded from the late Pleistocene assemblages in the region and were 

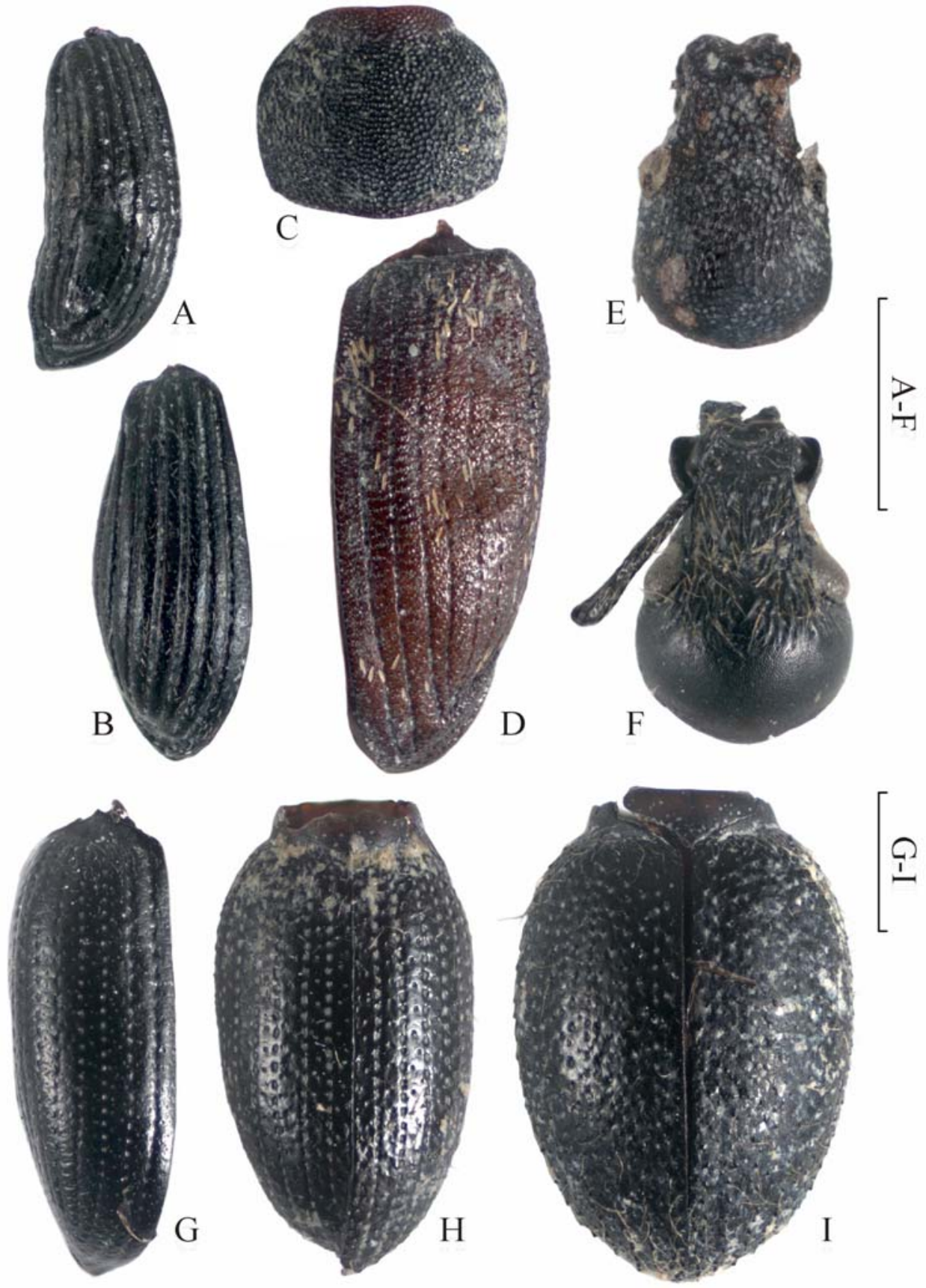

Fig. 2. Sub-fossil beetle fragments from the Kizikha-2 (A) and Kizikha-1 (B-I) assemblages:

A - Eutrichapion viciae, B - Hemitrichapion alexsandri, C, D - Tychius albolineatus, E - Paophilus albilaterus, F - Otiorhynchus sushkini, $\mathrm{G}-$ O. altaicus, $\mathrm{H}-$ O. ursus, I - O. obscurus. A-B, D, G-I - elytra, C - pronotum, E-F - head. Scale bars $1 \mathrm{~mm}$.

Рис. 2. Фрагменты Coleoptera из местонахождений Кизиха-2 (А) и Кизиха-1 (B-I):

A - Eutrichapion viciae, B - Hemitrichapion alexsandri, C, D - Tychius albolineatus, E - Paophilus albilaterus, F - Otiorhynchus sushkini, G - O. altaicus, H - O. ursus, I - O. obscurus. A-B, D, G-I - надкрылья, C переднеспинка, E-F - голова. Масштабные линейки 1 мм. 
Table 4. Szymkiewicz-Simpson similarity coefficients between three samples from Kizikha-1 site. Таблица 4. Коэффициенты сходства (Шимкевича-Симпсона) между пробами местонахождения Кизиха-1, \%.

\begin{tabular}{cccc}
\hline Samples & $\mathbf{1}$ & $\mathbf{2}$ & $\mathbf{3}$ \\
\hline $\mathbf{1}$ & 100 & 82 & 45 \\
$\mathbf{2}$ & 85 & 100 & 45 \\
$\mathbf{3}$ & 64 & 82 & 100 \\
\hline
\end{tabular}

Left below is species composition similarity, upperside right is abundance $\left(N_{\min }\right)$ similarity

Внизу слева - сходство по видовому составу, вверху справа - сходство с учётом обилия $\left(N_{\min }\right)$.

known from northernmost sites in West Siberia (as Curtonotus torridus) (Zinovyev, 2011), from the regions as follows: Western Europe, NorthEast Siberia, North America (Thanatophilus trituberculatus, Eutrichapion viciae, Sitona lineellus) (Andersson, 1992; Kuzmina, Mattews, 2012), or from Holocene sub-fossil assemblages in South part of West Siberia (Bembidion obscurellum, Aphodius granarius) (Gurina et al., 2016; Gurina, 2019). Six species including four endemic to the Altai-Sayan Mountain system have not been recorded in sub-fossil assemblages before (see above).

Contrariwise, sub-fossil assemblage of Kizikha-2 are dominated by Carabidae beetles while Curculionidae are represented more poorly (Table 3). The genus Otiorhynchus is represented by two moderately numerous species. The same supraspecific taxa ratio is characteristic to late Pleistocene insect assemblages from northernmost sites in West Siberia (Zinovyev, 2008, 2011), and for Novaya Surtaika site in northern foothills of Altai mountains (Dudko etal., 2017). In addition, Carabidae domination is typical to Holocene assemblages of southeastern part of West-Siberian Plain (Gurina et al., 2016; Gurina, 2019). In spite of atypical taxa ratio in Kizikha-2 site the most part of the species are recorded previously in late Pleistocene fauna of south-east part of West Siberia (Zinovyev et al., 2016; Gurina et al., 2018, 2019).

\section{Ecological preferences}

Most of the species found in Kizikha-1, Poecilus hanhaicus, Cymindis rostowtzovi, Hemitrichapion alexsandri, Tychius albolineatus, Paophilus albilaterus, Otiorhynchus alta- icus, O. ursus, O. obscurus, O. sushkini, O. unctuosus prefer steppe biotopes. The species assemblage typical of mesophyte and mesoxerophytous meadows is also well represented, namely: Curtonotus torridus, Clivina fossor, Cidnopus parallelus, Pristilophus punctatissimus, Eutrichapion viciae, Sitona ambiguus, $S$. lineellus, S. ovipennis, Polydrusus amoenus, Otiorhynchus politus. Both in steppe and in meadow assemblages a significant portion of the species consists of species developing and feeding on Fabaceae, namely: Hemitrichapion, Eutrichapion, Tychius, Sitona. The number of riparian species in the assemblage is relatively low, Bembidion obscurellum, Hypnoidus sp., Oedostethus sp., probably Bembidion sp. and Paederinae indet., one species, Centorus cf. rufipes, has an obligatory association with with saline habitats. No one species associated with trees or forest biotopes as well as tundra-bog or wet meadows was found at this site.

The different ratio of ecological groups in samples indicates vary taphonomic condition of sedimentation. So, in the sample 1 and especially in the sample 2 are dominated by species of meadows both by number and by species richness with the dominance of Otiorhynchus politus. In the sample 3 most number of species are typical representatives of steppes with dominance of $O$. ursus.

Ecological composition of species in Kizikha-2 site generally is similar to that of the Kizikha-1. In this site is also presented steppe species, Poecilus cf. ravus, Phyllobius femoralis, Otiorhynchus altaicus, O. ursus, as well as meadow species, Eutrichapion facetum, Zacladus geranii, Phyllobius virideaeris). Complex of species associated with moist habitats in 
Kizikha-2 is more diverse in comparison with Kizikha-1 site. There were found river bank species, Bembidion almum, Bembidion spp., Dyschiriodes sp., Stenus sp., Hypnoidus sp., including stony beaches, $B$. cf.fellmanni, and of river valleys, Amara aurichalcea, and also typical to moist meadows and boggy banks Tournotaris bimaculata. More abundant is a complex of species with obligatory association with saline habitats, Dyschiriodes rufimanus, Pogonus punctulatus, Bembidion (Emphanes) sp. Species typical to forest landscapes have not been found in the assemblage of Kizikha-2.

Thus, there may have been open steppe and meadow landscapes at the site according to ecological composition of species found in the both sites but ratio between steppe and meadow areas is difficult to identify. In spite of the fact that meadow species in both sites present significant share, very probably the main zonal landscape was represented by steppe while meadows covered river valleys or wet depressions. High number of dry-adapted (steppe) species, presence of species with obligatory assoication with saline habitats and absence of forest species indicate a dry climate. The high number of meadow species can be explained by taphonomic specificity. This suggestion is indirectly confirmed by differences in steppe and meadow species ratio in three samples from the Kizikha1 site and significant number of steppe species in the sample 3. Perhaps, meadows in the studied sites have been more expanded in comparison with the other studied deposits of southern part of West Siberian Plain due to close location to Altai mountains providing more mild climate. The hilly relief, well developed in Pleistocene, can also define distribution of meadows. Mesic meadows may have been formed on northern slope exposition while steppes developed on southern one. Hilly relief may also determined the absence of species associated with moist meadow habitats in Kizikha- 1 site.

\section{Distribution analysis}

Analysis of contemporary distribution of species that were found in sub-fossil assemblag- es significantly increase data needed for paleoenvironmental reconstruction. 12 species (48\%) found from the Kizikha-1 site occurred present in the region of North-East Altai foothills (Clivina fossor, Bembidion obscurellum, Aphodius granarius, Pristilophus punctatissimus, Eutrichapion viciae, Tychius albolineatus, Sitona ambiguus, S. lineellus, Paophilus albilaterus, Otiorhynchus obscurus, O. subocularis, O. unctuosus). Present day distribution areas of the remaining species are shifted to northern, eastern or southern directions (Table 5). The same changes of the distribution range configuration are typical to species found in other late Pleistocene insect assemblages from the southern part of West Siberian Plain, and shows that climatic conditions at the end of Pleistocene were significantly different as compared to the present time (Zinovyev et al., 2016; Gurina et al., 2018, 2019).

Five species are distributed north of the deposit, among them Curtonotus torridus, Thanatophilus trituberculatus and Sitona cf. ovipennis are typical of tundra and taiga zones i.e. of arcto-boreal distribution (Khruleva, Korotyaev, 1999; Nikolajev, Kozminykh, 2002; Kolesnikova et al., 2016). Boreomontane species Polydrusus amoenus and Otiorhynchus politus occur in meadows of taiga zone and in Altai-Sayan region are typical of highland alpine meadows and mountain tundra (Arnoldi, 1975; Legalov, 2013). Presence of arctoboreal and boreomontane species in sub-fossil insect assemblage indicates cold conditions during the end of Sartan stadial (MIS 2), the end of Last Glacial Maximum.

Six species from "Southern and Eastern complexes" of insect assemblages of Kizikha-1 are of the modern range in mountain steppes of Central and East Kazakhstan (Otiorhynchus altaicus, O. ursus) or Altai-Sayan mountainous system (Poecilus cf. hanhaicus, Cymindis cf. rostowtsowi, Hemitrichapion alexsandri, Otiorhynchus sushkini). Absence of these species in steppe zone of West Siberian Plain affirms their stenotopic character and preference of specific intermountain trough conditions by the species. Endemic species of intermountain troughs of 
Table 5. Modern distribution of species from Kizikha-1 and Kizikha-2 sites, species number. Таблица 5. Современное распространение видов из местонахождений Кизиха-1 и Кизиха-2, число видов.

\begin{tabular}{lcc}
\hline \multicolumn{1}{c}{$\begin{array}{c}\text { Distribution in comparison with } \\
\text { Kizikha sites }\end{array}$} & Kizikha-1 site & Kizikha-2 site \\
\hline Occurred on the region & 12 & 8 \\
Northern & 5 & 2 \\
Eastern & 5 & 2 \\
Southern & 3 & 3 \\
\hline
\end{tabular}

Altai-Sayan mountainous system have been recorded from late Pleistocene (late Karginian and Sartan) deposits of the southern part of West-Siberian Plain. In addition to four species from Kizikha-1 mentioned above a number of species are known with similar distribution, namely: Stephanocleonus favens Faust, 1884, S. tschuicus Suvorov, 1912, S. grigorievi Suvorov, 1915, S. isochromus Suvorov, 1912, S. luctuosus Faust, 1895, S. prasolovi Ter-Minasian, 1990, S. suvorovi Legalov, 1999, Otiorhynchus beatus Faust, 1890, O. janovskii Korotyaev, 1990, Eremochorus mongolicus (Motschulsky, 1860), Chlorophanus tuvensis Korotyaev, 1992 (Zinovyev et al., 2016; Gurina et al., 2018, 2019; Gurina, 2019). Many of these species are known from Chuiskaya Hollow and neighbouring territories of South-Eastern Altai and this fact may affirm similarity between recent landscapes of South-Eastern Altai and late Pleistocene landscapes of southern part of West Siberia. A conclusion about close similarity of the contemporary ecosystems of SouthEastern Altai and Pleistocene steppe-tundra of Southern Siberia and Europe has been deduced on the basis of plant and small mammal material (Chytrý et al., 2019).

Half of beetle species from the Kizikha-2 assemblage are not included in the modern fauna of the region and their distribution has shifted in northern, southern or eastern directions (Table 5). The "Northern complex" is represented by the only two species of floodplains, Bembidion cf. fellmanni and Amara aurichalcea. Both species are typical of tundra and northern taiga zones (Akopyan, 2015), but in mountains of Southern Siberia and the Far
East of Russia they extend down to foothills (Kobrakova et al., 2014). Riparian species Bembidion almum is widely spread in steppe and semi-desert zones of Eurasia together with Otiorhynchus altaicus and O. ursus mentioned above are belonging to the "Southern complex". The "Eastern complex" is represented with $\mathrm{Po}$ ecilus cf. ravus and Phyllobius femoralis widespread in steppes of Southern Siberia and Mongolia. Both species were recorded in late Pleistocene deposits of southern part of South Siberia (Zinovyev et al., 2016; Gurina et al., 2019), and Poecilus cf. ravus was recorded also in the northern part of West Siberian Plain at N 61.5 in the Aganskii Uval-1290/2 deposit (Zynovyev, 2011). Dry and cold climate can be reconstructed for Karginian Interstadial (MIS 3) according to these data. However due to poor representation of the species of northern complex and their weak "cold resistance" more mild environmental conditions can be supposed in comparison with the end of Sartan stadial (MIS 2) of the Kizikha-1 site.

\section{Comparison of the insect sub-fossil} species composition with the late Pleistocene entomofauna of West Siberian Plain

The studied sites are important to understand distribution of paeoentomofauna of the region due to their southernmost locality among the known Pleistocene deposits of West Siberian Plain. Deposits studied before allowed study patterns of zonal changes of entomofaunas at the end of Karginian interstadial (MIS 3). 16 sites in West Siberian Plain located in latitudi- 


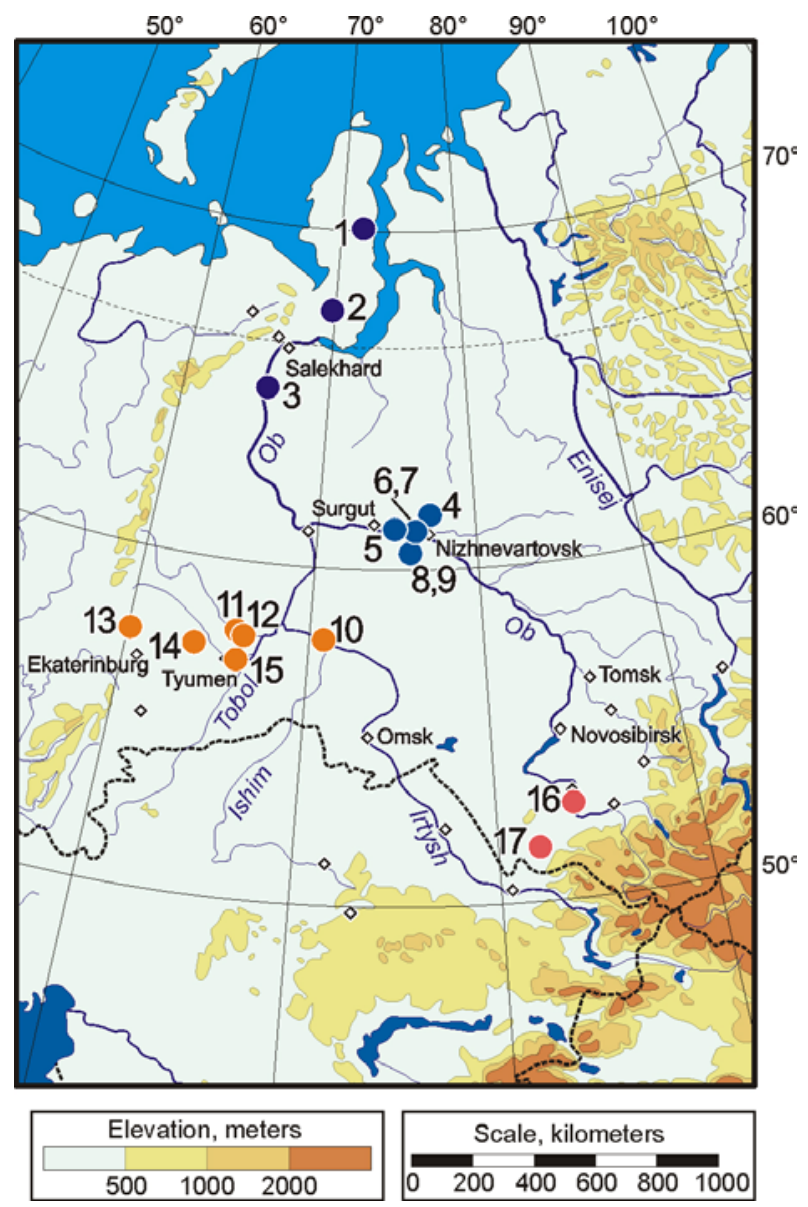

Fig. 3. MIS 3 deposits studied from West Siberian Plain and the Urals with types of entomocomplexes. Sites: 1 - Syoyakha-Mutnaya, 2 - Tyurseda-Khadyta, 3 - $430 \mathrm{~km}$ of Ob, 4 - Aganskiy Uval-1290/2, 5 - Lokosovo, 6-Mega-2169, 7 - Mega-2172, 8-9 - Kul'egan-2247 (clearances I and II), 10 - Skorodum-95, 11 - Andryushino, 12 - Nizhnyaya Tavda, 13 - Shurala, 14 - Nikitino, 15 - Mal'kovo, 16 - Kalistratikha, 17 - Kizikha-2. Entomocomplexes: 1-9 - Arctic type (1-3 - analogs of the recent Arctic faunas, 4-9 - Arctic faunas with steppe elements); 10-17 — steppe type ("Otiorhynchus-type" complexes) (10-15 — with Arctic and arctoboreal elements, 1617 - with a single arctoboreal elements).

Рис. 3. Изученные местонахождения периода окончания МИСЗ Западно-Сибирской равнины и Урала и выявленные типы энтомокомплексов.

Местонахождения: 1 - Сёяха-Мутная, 2 - Тюрседа-Хадыта, 3 - 430 км Оби, 4 - Аганский увал-1290/2, 5 Локосово, 6 - Мега-2169, 7 - Мега-2172, 8-9 - Кульеган-2247 (расчистки I и II), 10 - Скородум-95, 11 Андрюшино, 12 - Нижняя Тавда, 13 - Шурала, 14 - Никитино, 15 - Мальково, 16 - Калистратиха, 17 Кизиха-2. Энтомокомплексы: 1-9 - арктического типа (1-3 - аналоги современных арктических фаун, 4-9арктические фауны с присутствием степных элементов); $10-17$ - степного типа («отиоринхусные» комплексы) (10-15 - с присутствием арктических и арктобореальных элементов, 16-17 - с присутствием единичных арктобореальных элементов).

nal gradient from $70^{\circ} \mathrm{N}$ (Syoyakha-Mutnaya) till $53^{\circ} \mathrm{N}$ (Kalistratikha) (Zinovyev, 2008, 2011, 2016; Gurina et al., 2018) (Fig. 3) were described from this period of time. Entomocomplexes from deposits of northern part of West
Siberian Plain $\left(70-60^{\circ} \mathrm{N}\right)$ are mainly represented by ground beetles with domination of species with contemporary arctic (Curtonotus alpinus (Paykull, 1790), Pterostichus costatus (Ménétriés, 1851), P. vermiculosus (Ménétriés, 1851), 
P. sublaevis (J.R. Sahlberg, 1880)) and arctoboreal (Diacheila polita (Faldermann, 1835), Pterostichus (Cryobius) spp., Curtonotus torri$d u s)$ distribution. These complexes are very similar to contemporary arctic faunas especially in northernmost localities $\left(60-70^{\circ} \mathrm{N}\right)$. Presence of single steppe species (Poecilus cf. ravus, Aclypea bicarinata (Gebler, 1830), Stephanocleonus eruditus Faust, 1890), non-typical of contemporary Arctic, are attaching specifics to the entomocomplexes of southernmost deposits $\left(62-60^{\circ} \mathrm{N}\right)$.

Entomocomplexes from southernmost sites of West Siberian Plain $\left(58-53^{\circ} \mathrm{N}\right)$ differ in their specific characteristics (Fig. 3). The entomocomplexes are not analogous to recent fauna (Zinovyev, 2011; Legalov et al., 2016; Gurina et al., 2018, 2019) and differ by the following characters: 1. Domination of Curculionidae species; 2. Domination of Otiorhynchus specimens, especially of $O$. altaicus and $O$. ursus, which are distributed in Central and Eastern Kazakhstan at present time; this fact is the most characteristic difference and is thus named as "Otiorhynchus-type" fauna from all known quaternary entomofaunas of the other regions (Zinovyev, 2011); 3. Steppe species prevail, species associated with saline habitats (Pogonus punctulatus, Centorus rufipes) are present, fewer in number are tundra species and almost completely absent are forest (taiga) species; 4. A major number of species from sub-fossil assemblages are absent in recent regional fauna. Presence of arctoboreal and boreal species in late Karginian sub-fossil insect assemblages in southern part of West Siberian Plain define cold climatic conditions in comparison with the present time. A number of arcto-boreal species mainly typical of tundra zone, Diacheila polita, D. arctica, Curtonotus alpinus, Stereocerus haematopus (Dejean, 1831), were recorded in more or less northern deposits Nikitino, Andryushino, Skorodum and others (Zinovyev, 2003, 2011). Only two arctoboreal species, Nebria cf. nivalis (Paykull, 1790) and Notharis aethiops (Paykull, 1792), were detected from more southern deposit Kalistratikha (Gurina et al., 2018). Both species are typical of tundra zone and intrazonal riparian biotopes of taiga zone.
Kizikha-2 site is also of late Karginian age is located nearly $150 \mathrm{~km}$ to the south of Kalistratikha. Faunal composition of species is characterized as "Otiorhynchus-type" of northern areas, but $O$. altaicus and O. ursus in this assemblage are not dominant. Weakly represented arctoboreal species (see above) allow reconstructing similar natural conditions in both sites.

Zonal distribution of entomocomplexes in Sartan stadial of West Siberian Plain could not be precisely characterized due to incompleteness data. Site Kizikha-1 is close to Bun'kovo deposit $\left(55^{\circ} \mathrm{N}, 11550 \pm 125{ }^{14} \mathrm{C} \mathrm{BP}\right)$ (Zinovyev et al., 2016), and entomocomplexes are like to each other, and similar to late Karginian fauna of the region. Domination of Curculionidae and especially the genus Otiorhynchus in combination with the absence of the most part of the species in contemporary fauna is characteristic. The share of cold-adapted arcto-boreal species is higher in Sartan entomocomplexes that in late Karginian. For example, Pelophila borealis (Paykull, 1790), Coccinella nivicola Mulsant, 1850, Lepyrus nordenskioldi Faust, 1887 were present in Bun'kovo deposit (Zinovyev et al., 2016). Differences between insect assemblages from Bun'kovo and Kizikha-1 by ecological preferences of the species (higher number of mesic meadow species and absence of wet bog species in the latter deposit), probably, were caused by taphonomic but not climatic factors.

\section{Conclusions}

The southernmost West Siberia deposits of late Plestocene insect sub-fossils, Kizikha-2 (late Karginian age, MIS 3) and Kizikha-1 (late Sartan age, MIS-2) are found on the banks of river Kizikha, Altaiskii Krai of Russia.

The list of 51 species of Coleoptera represents insect assemblages of the studied sites. Beetle complexes from both sites coincides with late Pleistocene "Otiorhynchus-type" fauna of southern part of West Siberian Plain (Zinovyev, 2011; Legalov et al., 2016) by the characters as follows: domination of Otiorhynchus species, steppe species prevail, presence of species, associated with saline habitats, ab- 
sence forest species, a number of species absent in a regional fauna, some of them are belonging to northern (arcto-boreal) and another ones to southern (subboreal species) complexes, also characteristic presence of endemic species of intermountain troughs of Altai-Sayan mountainous system.

Specifics of the both sites as compared with the other late Pleistocene faunas of West Siberian Plain is in high proportion of meadow species that could be explained by taphonomic condition of sedimentation or microclimatic conditions caused by close location to Altai mountains.

In the sub-fossil assemblage of Kizikha-2 is dominant in Carabidae while species of the genus Otiorhynchus are only poorly represented. The northern complex of species is also weakly represented in the site.

Open steppe and meadow landscapes are reconstructed for both sites. Probably, steppe was zonal landscape while meadows were located in river floodplain and wet lowlands. Climate was dry and cold as compared with present time but natural conditions of the deposit Kizikha-2 (end of MIS 3) were more mild in comparison with Kizikha-1 (end of MIS 2).

Our study of species assemblages from the southernmost deposit, Kizikha-2, updated information on the latitudinal-zonal distribution of beetles in West Siberian Plain during the end of MIS 3, Karginian interstadial. Two types of the fauna were existed according to analysis of material from 16 sites. Arctic fauna of Coleoptera of the late Karginian period at the area limited by $70-60^{\circ} \mathrm{N}$ is analogous to contemporary Arctic fauna, but in the southernmost localities were some steppe species non-typical of contemporary Arctic. So called "Otiorhynchustype" beetle fauna $\left(58-51.5^{\circ} \mathrm{N}\right)$ differs strongly from the fauna of contemporary natural zones of West Siberian Plain. Domination of steppe beetles, Otiorhynchus altaicus, O. ursus and other species of the genus, is typical of this fauna. Arcto-boreal species are also present in "Otiorhynchus-type" beetle fauna decreasing their representation from north to the south up to single species in southernmost sites Kalistratikha and Kizikha-2 $\left(53-51.5^{\circ} \mathrm{N}\right)$.

\section{Acknowledgements}

The authors are gratitude to M.A. Kul'kova (Herzen State Pedagogical University, SaintPetersburg) for dating of the sample; we also thank E.R. Dudko and K.A. Tsepelev (Novosibirsk) for the help in collecting of samples and V.K. Zinchenko (Novosibirsk) for the identification of some species. We are especially grateful to Jonathan Cooter (Oxford University Museum of Natural History, UK) for his kind help with the final correction of the manuscript.

The study was supported by the Russian Foundation for Basic Research (grant No. 1904-00963a), the Federal Fundamental Scientific Research Programme for 2013-2020, grant No. VI.51.1.5 (AAAA-A16-116121410121-7) and Moscow State University research project No. AAAA-A16-116021660095-7.

\section{References}

Adamenko O.M. 1974. [Mesozoic and Cenozoic of the Steppe Altai]. Novosibirsk: Nauka. 168 p. [In Russian]

Akopyan E.K. 2015. [Caraboides (Insecta, Coleoptera, Caraboidea) of Khanty-Mansi Autonomous Okrug Yugra]. Dissertatsiya ... kandidata biologicheskikh nauk. Surgut: Surgut State University. 222 p. [In Russian]

Andersson G. 1992. Arkeo-entomologiska undersökningar i historisk tid i Göteborg // Entomologisk Tidskrift. Bd.113. S.7-14.

Arnoldi L.V. 1975. [Weevils of the genus Otiorrhynchus Germ. (Coleoptera, Curculionidae) of Mongolia and adjacent regions of the USSR] // Nasekomye Mongolii. Issue 3. Leningrad: Nauka. P.254-284 [in Russian].

Chytrý M., Horsák M., Danihelka J., Ermakov N., German D.A., Hájek M., Hájková P., Kočí M., Kubešová S., Lustyk P., Nekola J.C., Pavelková-Ričánková V., Preislerová Z., Resl P., Valachovič M. 2019. A modern analogue of the Pleistocene steppe-tundra ecosystem in southern Siberia // Boreas. Vol.48. P.36-56.

Coope G.R. 1959. A late Pleistocene insect fauna from Chelford, Cheshire // Proceedings of the Royal Society of London. Ser.B. Vol.151. No.942. P.70-86.

Dudko R.Yu., Gurina A.A., Dudko E.R., Zinovyev E.V., Tshernyshev S.E., Legalov A.A. 2017. Beetles (Coleoptera) in the late Pleistocene deposits on the Isha River in the foothills of the Northern Altai Mountains // XV s'ezd Russkogo entomologicheskogo obshchestva. Rossia, Novosibirsk, 31 July -7 August 2017. Materialy s'ezda. Novosibirsk. P.166-167 [in Russian].

Gurina A.A. 2019. [Late Quaternary Coleoptera of southeast West Siberian Plain]. Dissertatsiya ... kandidata 
biologicheskikh nauk. Novosibirsk: Institute of Systematics and Ecology of Animals of the Siberian Branch of the RAS. 129 p. [In Russian]

Gurina A.A., Dudko R.Yu., Zinovyev E.V., Borodin A.V., Tshernyshev S.E., Legalov A.A. 2018. Late Pleistocene Taphocoenosis of Insects and Small Mammals from the Upper Reaches of the Ob River // Paleontological Journal. Vol.52. No.13. P.1610-1622.

Gurina A.A., Dudko R.Yu., Zinoviev E.V., Zinchenko V.K., Tshernyshev S.E., Legalov A.A. 2016. [Subfossil insects from late Holocene alluvial deposits in the bank of river Alei, Altaiskii Krai, Russia] // Evraziatskii Entomologicheskii Zhurnal. Vol.15. No.6. P.555-562. [in Russian with English summary].

Gurina A.A., Dudko R.Yu., Tshernyshev S.E., Zinovyev E.V., Legalov A.A. 2019. Late Pleistocene insects from the Dubrovino site at Ob River (West Siberia, Russia) and their paleoenvironmental significance // Palaeontologia Electronica. Vol.22.1.3A. P.1-18. https://doi.org/10.26879/914

Kazmina T.A. 1975. [Stratigraphy and Ostracods of the Upper Pliocene and Lower Quaternary deposits of the south of the West Siberian Plain]. Novosibirsk: Nauka. 107 p. [In Russian]

Khobrakova L.Ts., Shilenkov V.G., Dudko R.Yu. 2014. [The Ground Beetles (Coleoptera, Carabidae) of Buryatia]. Ulan-Ude: Buryat Scientific Center SB RAS Press. 380 p. [In Russian with English summary]

Khruleva O.A., Korotyaev B.A. 1999. [Weevils (Coleoptera: Apionidae, Curculionidae) of Wrangel Island] // Entomologicheskoe obozrenie. Vol.78. No.3. P.648-670 [in Russian with English summary].

Kiselev S.V. 1973. [Late Pleistocene Coleoptera of the Trans-Urals] // Paleontologicheskii Zhurnal. No.4. P.70-73 [in Russian].

Kiselev S.V. 1988. [Pleistocene and Holocene Coleoptera of West Siberia] // Sovremennoe sostoyanie i istoria zhivotnogo mira Zapadno-Sibirskoi nizmennosti. Sverdlovsk. P.97-118 [in Russian].

Kolesnikova A.A., Dolgin M.M. Konakova T.N. 2016. [Zoogeographical characteristic of Carabidae of the European Nort-East of Russia] // Vestnik SAFU. Ser. Estestvennye nauki. No.1. P.61-79 [in Russian with English summary].

Kuzmina S.A. 2015. Quaternary Insects and Environment of Northeastern Asia// Paleontological Journal. Vol.49. No.7. P.679-867.

Legalov A.A. 2013. [Curculionoidea of high mountains from Altai] // Bioraznoobraziye, problemi ekologii Gornjgj Altaya i sopredel'nikh regionov: nastoyaschee, proshloe, buduschshee. Materialy Tretiey Mezhdunarodmoy Konferetsii. Gorno-Altaisk: RIO GAGU. P.85-86 [in Russian].

Legalov A.A., Dudko R.Yu. 2016. [The first records of quaternary insects in the south of West Siberia] // Priroda. No.10. P.90-92 [in Russian].

Legalov A.A., Dudko R.Yu., Zinovyev E.V. 2016. Subfossil weevils (Coleoptera, Curculionoidea) from the central part of West Siberia provide evidence of range expansion during the last glaciations // Quaternary International. Vol.420. P.233-241.
Nikolajev G.V., Kozminykh V.O. 2002. [The carrion beetles (Coleoptera: Agyrtidae, Silphidae) of Kazakhstan, Russia and adjacent countries]. Almaty: Kazakh Universiteti. 159 p. [In Russian with English summary] Revyakin V.S. 1995. [Geography of Altaiskii krai]. Barnaul: Altaian Book Publ. 136 p. [In Russian]

Rusakov A., Sedov S., Sheinkman V., Dobrynin D., Zinovyev E., Trofimova S., Maksimov F., Kuznetsov V., Korkka M., Levchenko S. 2019. Late Pleistocene paleosols in the extra-glacial regions of Northwestern Eurasia: Pedogenesis, post-pedogenic transformation, paleoenvironmental inferences // Quaternary International. Vol.501. P.174-192.

Rusanov G.G. 2010. [Holocene alluvium of the Kizikh River on the Pre-Altai Plain] // Izvestiya Biiskogo otdeleniya Russkogo geograficheskogo obshchestva. Issue 31. P.41-45 [in Russian].

Shavrin A.V. 2008. Distribution of the Silphidae (Coleoptera) in the Baical Region // Klapelekiana. Vol.44. P.271-287.

Sheinkman V., Sedov S., Shumilovskikh L., Korkina E., Korkin S., Zinovyev E., Golyeva A. 2016. First results from the late Pleistocene paleosols in northern Western Siberia: Implications for pedogenesis and landscape evolution at the end of MIS3 // Quaternary International. Vol.418. P.132-146.

Sher A., Kuzmina S. 2007. Beetle records: late Pleistocene of northern Asia // S.A. Elias (ed.). Encyclopedia of Quaternary Science. Amsterdam: Elsevier. P.246-267.

Sher A.V., Kuzmina S.A., Kuznetsova T.V., Sulerzhitsky T.D. 2005. New insights into the Weichselian environment and climate of the East Siberian Arctic, derived from fossil insects, plants and mammals // Quaternary Science Reviews. Vol.24. P.533-569.

Tsepelev K.A., Zinovyev E.V., Dudko R.Yu., Tshernyshev S.E., Legalov A.A. 2013. [Carrion beetles (Coleoptera, Silphidae) in Younger Dryas of Chick River (Late Pleistocene of Siberia)] // Evraziatskii Entomologicheskii Zhurnal. Vol.12. No.1. P.27-34 [in Russian with English summary].

Tshernyshev S.E., Tsepelev K.A., Dudko R.Yu., Zinovyev E.V., Legalov A.A. 2013. [Pill beetles (Coleoptera, Byrrhidae) in Late Neo-Pleistocene and Pleistocene deposits in the south of the West Siberia] // Evraziatskii Entomologicheskii Zhurnal. Vol.12. No.2. P.109-119 [in Russian with English summary].

[Unified regional stratigraphic scheme of the Quaternary deposits of the West Siberian Plain]. 2010. Novosibirsk. 64 p. [In Russian]

Zazhigin V.S. 1980. [Mammals and the Kochkovsky horizon] // Kochkovsky horizont Zapadnoi Sibiri i ego vozrastnye analogi v smezhnykh raionakh. Novosibirsk: Nauka. P.19-31 [in Russian].

Zinovyev E.V. 2003. [Late Karginian entomocomplexes of low reaches of Irtysh riveras exemplified by sites at Skorodum-95 and Kazakovka-95] // Evraziatskii Entomologicheskii Zhurnal. Vol.2. No.2. P.83-93 [in Russian with English summary].

Zinovyev E.V. 2008. A history of ground-beetle faunas of West Siberia and the Urals during the late Pleistocene 
to Holocene // L.D. Penev, T.L. Erwin, T. Assmann (eds.). Back to the Roots and Back to the Future. Towards a New Synthesis Amongst Taxonomic, Ecological and Biogeographical Approaches in Carabidology. Proceedings of the XIII European Carabidologists Meeting. Blagoevgrad, August 20-24, 2007. Sofia-Moscow: Pensoft Publishers. P.241-254.

Zinovyev E.V. 2011. Sub-fossil beetle assemblages associated with the "mammoth fauna" in the late Pleistocene localities of the Ural Mountains and West Siberia // ZooKeys. No.100. P.149-169.
Zinovyev E.V. 2016. [Review of late Pleistocene and Holocene localities of insects from the north Western Siberia and the Urals] // Vestnik NVGU. No.2. P.2336 [in Russian with English summary].

Zinovyev E.V., Dudko R.Yu., Gurina A.A., Prokin A.A., Mikhailov Yu.E., Tsepelev K.A., Tshernyshev S.E., Kireev M.S., Kostyunin A.E., Legalov A.A. 2016. First records of sub-fossil insects from Quaternary deposits in the southeastern part of West Siberia, Russia // Quaternary International. Vol.420. P.221-232.

Responsible editor A.A. Kotov 